\title{
Technological Solutions for Processing Closed Coal Mines by Open Pit Method
}

\author{
Vladimir Makarov ${ }^{1, *}$, Péter Kovacs ${ }^{2}$, Samuel Dagmar ${ }^{3}$, and Riccardo Paulman ${ }^{3}$ \\ ${ }^{1}$ CJSC Stroyservice, 650055 Kemerovo, 121 Kuznetsky Avenue, Russian Federation \\ ${ }^{2}$ University of Miskolc, H-3515 Egyetemváros, Miskolc, Hungary \\ ${ }^{3}$ Queensland University of Technology, 2434 QLD 4001, Brisbane, Australia
}

\begin{abstract}
The main sources of environmental pollution are: pollution from the residual effects of working out of mine fields by underground method; pollution from secondary mining of mine fields by the open method. The pollution of the environment from the underground mining of mine fields is mainly due to the erosion of the surface of the ditches caused by collapse of the underground workings, spontaneous combustion of the remaining coal reserves and exit of poison gases $\mathrm{SO} 2$ and $\mathrm{CO}$ to the surface through the cracks from the lower horizons of the worked-out mine fields. This makes actual the research of technological possibilities of harmful emissions reducing when quarrying underground mines' fields. The environment deterioration from conducting open pit mining operations in the underground mine fields is caused by the technological processes of quarrying (preparation of rock for excavation, excavation, transportation of rocks and coal, dumping), by the objects of the open pit infrastructure (industrial site, transport communications, trenches and other workings, coal storage and rock dumps). The main direction of eliminating the negative environmental consequences of underground mining is the localization or complete isolation of the underground mines influence' on the surface.
\end{abstract}

\section{Introduction}

The negative influence of the technological processes of open pit mining is associated with drilling and blasting operations during loosening of hard rock with the emissions of dust and gas clouds, which includes fine-grained rock particles and poison gases. The main direction of reducing or eliminating this impact is the transition to a non-explosive technology for the development of hard overburden rock or the introduction of a hydraulic breakage and foam tamping of wells that reduce the release of toxic agents into the environment.

The negative impact of excavating and loading operations on the environment is affected by the formation of a dust cloud in the face when digging and loading rock into transportation vessels [1-2].

\footnotetext{
*Corresponding author: v.makarov@stroyservice.com
} 


\section{Methods}

Reducing the impact of excavating and loading operations can be reduced through the rationalization of the technological cycle operations of the excavators and the irrigating the face [3].

For overburden and coal transportation, the environment pollution occurs as a result of wind or air impact on the transported material during the dump truck movement with the formation of a dust trail of fine particles.

In addition, when the dump truck moves along the quarry roads, a dust emission from the milling of rocks occurs as a result of their interaction with the wheels (this is a sort of wheeled "crusher" of rocks).

A significant contribution (up to $30-40 \%$ ) to pollution of the environment is made by the flap gases from the operation of the engines of dump trucks [4-5].

Reduction of the negative impact on the environment from this process is possible by isolating the cargo carried by spraying protective film, reducing the length of transportation, rational combination of the excavator bucket capacity and the capacity of the dump body. Reduction of dust formation on roads during the movement of dump trucks can be achieved by the systematic irrigation of roads with coagulating liquid emulsion and cleaning roads from spills of rocks and coal.

The formation of dust emissions into the environment (atmosphere, hydrosphere and soil) occurs during the unloading of dump trucks on rock dumps and coal depots [6-7].

Reduction of dust emissions during this process is possible due to the rationalization of technological parameters of the dump-formation schemes, the choice of the location of the dump, the mode of unloading the dump truck, the method of dumping [8].

\section{Results \& Discussion}

The structure of the underground and open pit mine impact on the environment is shown on Fig. 1.

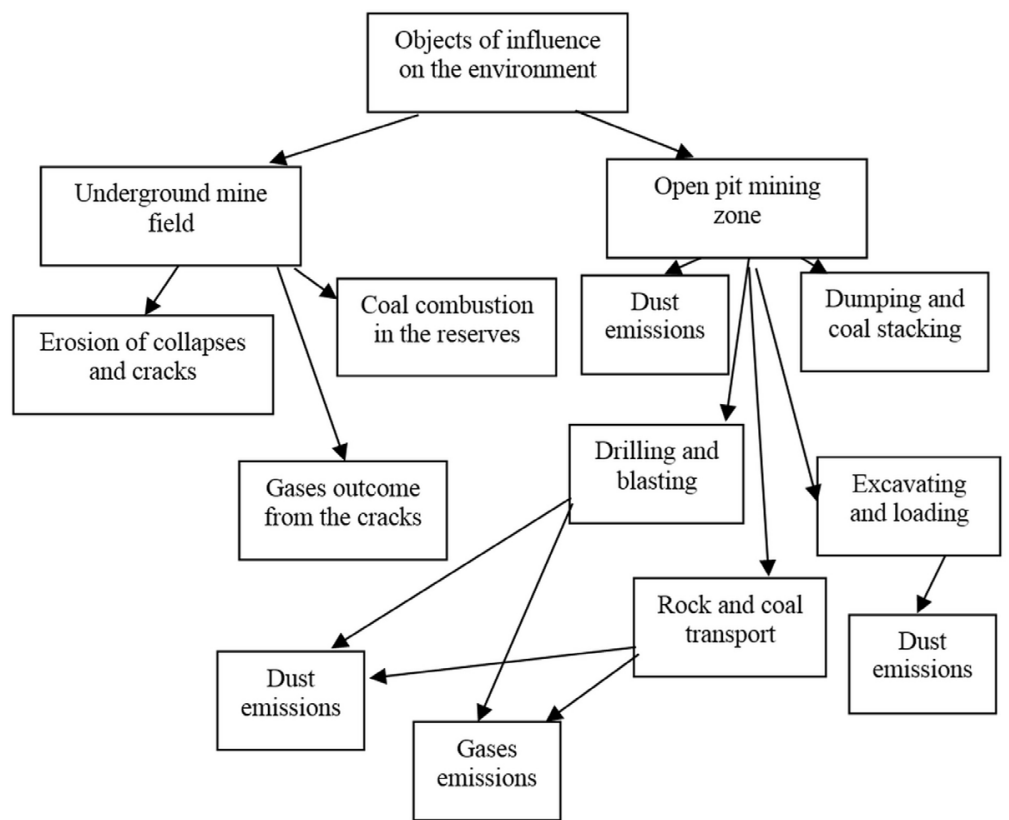

Fig. 1. The structure of harmful impact on the environment in open pit mining of closed underground mine's field. 
In the process of working out the underground mine field by quarrying, there is a reduction of harmful emissions into the environment - the consequences of underground mining - due to a reduction in the surface area of the underground mine field exposed to the influence of underground mine workings.

However, at the same time there are new sources of environmental pollution from the impact of open pit mining. Therefore, the problem of minimizing the general polluting effects on the environment arises.

Reduction of environmental pollution by infrastructure facilities is achieved through their optimal location, taking into account the direction of airflows over this territory and equipping sources of emission by aspiration systems and installations of dust and gas trap equipment.

Having considered the factors that adversely affect the environment during the development of mine fields by the open method, it can be stated that it is necessary to search for new technological and technical solutions that ensure the elimination of the polluting effect of mine fields on the environment.

Without the search for such solutions, the negative impact of mine fields on the ecological situation will continue for decades, and perhaps even centuries, which will irreparably damage the ecology of coal mining region.

The cardinal decision to protect the environment from the negative impact of mine fields, worked out underground, is the ecological rehabilitation of the open pit with complete reclamation of the surface of the underground mine field.

We have considered the following sanitation options:

- partial reorganization of the underground mine field with additional extraction of the remaining coal reserves from the seams from their outcrops under the washes by hydraulic backhoes and special excavating units;

- continuous working of the upper part of the underground mine field by a horizontal layer by direct dumping technology with the transverse movement of the mining front.

At the same time, each of these options provides for a set of measures to reduce the negative impact of open pit mining on the environment in the process of sanitation of underground mine fields.

In the process of extracting the remaining coal reserves from the underground mine fields by quarrying, the reclamation of disturbed lands must be planned following the advance of the mining front.

Moreover, a separate excavation of overburden rock, potential-fertile rocks, a fertile layer and coal seams is carried out. At the stage of the technical reclamation, the hard rocks in internal dump are filled with potentially fertile rocks, which, in turn, are covered with a fertile layer followed by a biological stage of reclamation.

Thus, the whole complex of works on the transformation of underground mine surface into an ecologically safe condition is carried out, followed by its use in the national economy.

The parameters of the preparatory trench for partial sanitation of underground mine fields are determined on the basis of the possibility of coal seam excavating by hydraulic excavator (Fig. 2). 


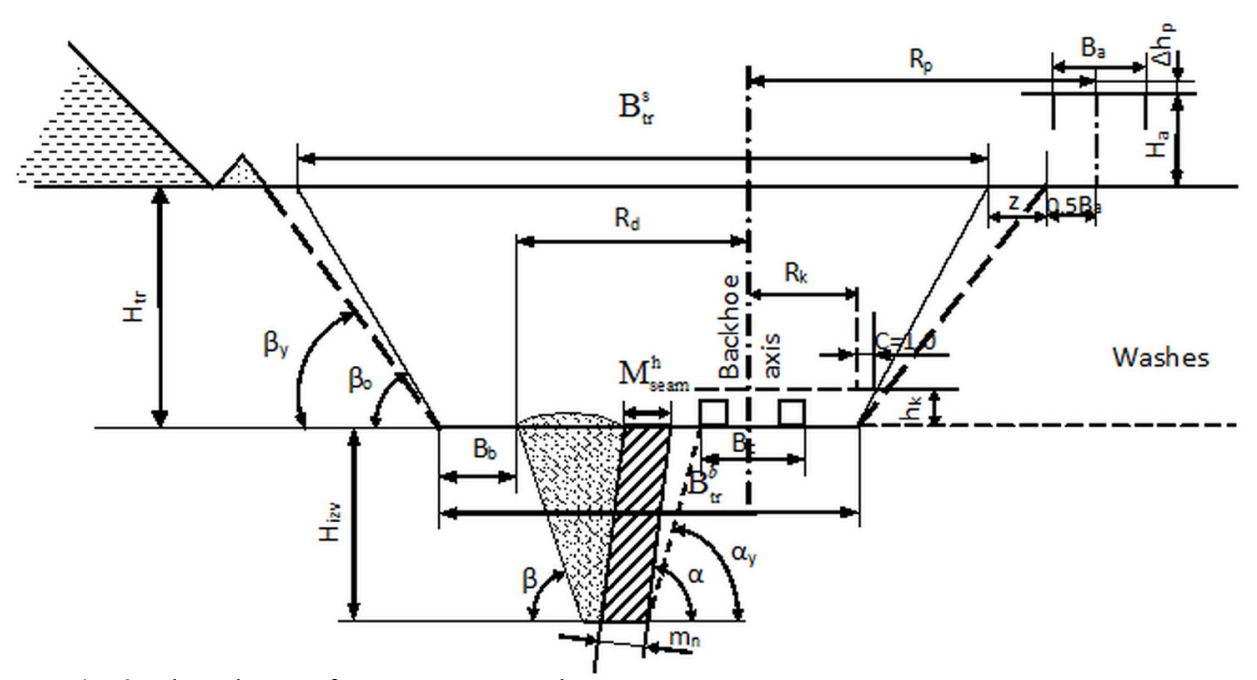

Fig. 2. The scheme of preparatory trench parameters.

The minimum width of the trench bottom is defined from the formula:

$$
\mathrm{B}_{\mathrm{tr}}^{b}=\mathrm{H}_{\mathrm{izv}}\left(\operatorname{ctg} \beta+\operatorname{ctg} \alpha_{\mathrm{y}}\right)+\frac{\mathrm{m}_{\mathrm{n}}}{\sin \alpha}+\mathrm{R}_{\mathrm{k}}+0.5 \mathrm{~B}_{\mathrm{c}}+\mathrm{C}+\mathrm{B}_{\mathrm{b}}-\mathrm{h}_{\mathrm{k}} \cdot \operatorname{ctg} \beta_{\mathrm{o}}+\mathrm{B}_{\mathrm{k}}
$$

where $H_{i z v}$ - the depth of coal seams extraction, $\mathrm{m} ; \beta$ - the slope angle of the working, degrees; $\alpha$ - dip angle of a seam, degrees; $\alpha_{y}$ - the sustainable slope angle for rock in the seam's bed, degrees; $m_{n}$ - normal thickness of a seam, $\mathrm{m} ; B_{c}$ - the width of the backhoe caterpillars $\mathrm{m} ; B_{k}$ - the width of the bucket, $\mathrm{m} ; R_{k}$ - the excavator's body turning radius, $\mathrm{m}$; $C$ - the distance between trench slope and the excavator's body, $\mathrm{m} ; B_{b}$ - the safety berm, m; $h_{k}$ - the distance between excavator's body and preparatory trench bottom, $\mathrm{m} ; M^{h}$ seam - the horizontal thickness of a seam, $m$.

The width of the preparatory trench on the surface is defined as:

$$
\mathrm{B}_{\mathrm{tr}}^{\mathrm{s}}=\mathrm{B}_{\mathrm{tr}}^{b}+2 \mathrm{H}_{\mathrm{tr}} \times \operatorname{ctg} \beta_{0}
$$

where: $H_{t r}-$ the depth of preparatory trench, $\mathrm{m} ; \beta_{0}-$ the slope angle of the preparatory trench, degrees.

The advanced excavation of coal seams by a hydraulic backhoe can be made accordingly to the following options:

- loosening of rocks from the hanging wall of the seam with the use of drilling and blasting operations;

- excavation of rocks from the hanging wall of the seam without the use of drilling and blasting operations;

- excavation of rocks from the hanging wall of the seam without the use of drilling and blasting operations with preliminary treatment with surfactants.

The following technology options are possible:

- excavation of the blasted rock from the hanging side of the seam immediately to the full depth, followed by excavation of the coal seam;

- excavation of the rocks treated with surfactant from the hanging wall of the seam by layer with subsequent extraction of the coal seam within the bed; 
- advanced excavation of the coal seam by layer with subsequent excavation of rocks from the hanging wall of the seam by layer with their forced collapse.

\section{Conclusion}

Thus the fulfilling the conditions of reducing environmental load at open pit mining of the coal seams in underground mine field requires justification and choice of optimal parameters of quarry workings and a scheme of their development.

\section{References}

1. M. Prekopová, J. Janočko, V. Budinský, M. Friedmannová, Environmental Earth Sciences, 76:1, 25 (2017)

2. D. Hrehová, M. Cehlár, R. Rybár, N. Mitterpachová, Mining technology with drillingblasting operations, 12th International Multidisciplinary Scientific GeoConference and EXPO - Modern Management of Mine Producing, Geology and Environmental Protection, SGEM 2012, 1, 675-682 (2012)

3. T. Gvozdkova, S. Markov, N. Demirel, S. Anyona, E3S Web of Conferences 21, 01024 (2017)

4. S. Markov, V. Martyanov, E. Preis, A. Abay, E3S Web of Conferences 21, 01021 (2017)

5. V. Gogolin, Y. Lesin, A. Djagileva, E3S Web of Conferences, 15, 01001 (2017)

6. V. Kolesnikov, O. Litvin, J. Janočko, A. Efremenkov, E3S Web of Conferences, 21, 01031 (2017)

7. M. Tyulenev, O. Litvin, M. Cehlár, S. Zhironkin, M. Gasanov, Acta Montanistica Slovaca, 22:3, 296-302 (2017)

8. M. Tyulenev, S. Zhironkin, E. Tyuleneva, A. Abay, S. Anyona, M. Hellmer, Coal International, 265:3, 30-34 (2017) 